\title{
Notes for Symposium on Black Power
}

\author{
January 6, 1967
}

Beerman's notes for this symposium on Black Power offer insight into the radical cast of his thought. He was writing in a time of growing unrest and consciousness-raising regarding race relations in the United States. Somewhat unusually for a rabbi sitting in upscale Bel-Air, he evinced considerable sympathy for the banner of Black Power, deeming it an essential rallying cry for the disaffected African American underclass. He evoked the words of Black Power leader Stokely Carmichael, who would earn the opprobrium of many in the Jewish community because of his strong anti-Zionist stance. Beerman asserted that, through his critique of integration, Carmichael was pushing toward a state of "psychological equality" in which black people would be empowered to lift themselves out of the state of poverty and deprivation in which white America continued to place them. Beerman affirmed that drive as an antidote to what he saw as the institutional racism of America.

The call for Black Power issued by the Student Nonviolent Coordinating Committee emerged on the Mississippi march led by James Meredith last July. But the concept of Black Power is not a recent phenomenon. It has grown out of the agitation and the activity of different people and organizations in many Negro communities over the years.

No organization has been able to speak to the growing militancy of young Negro people living in the urban ghetto. The significance of Black Power as a slogan is that black people are going to use the words they want to use. Black people are working to provide the Negro community with a position of strength or power from which to make its voice heard.

The double reality of Negro life in America is that Negroes are poor and they are black. All of the other problems afflicting the American Negro arise from this 
two-sided reality. The advocates of Black Power are attempting to win political power for impoverished Southern blacks. They are convinced that this is a country which does not function by morality, love, and non-violence, but by power. The purpose of political power and its achievement is that the community thus represented can make or participate in making the decisions which will govern their destinies, and thus bring about basic change in their day-to-day living. To achieve political power meant the struggle to achieve the right to vote in an atmosphere of racist terror, which ruled large sections of the deep South until recent years. Voter registration drives were begun. In Alabama, candidates for sheriff taxassessors were placed on the ballot, and the symbol of their party was a panther, a bold, beautiful animal representing the strength and dignity of the black people, Stokely Carmichael says. Politically, Black Power means the coming together of black people to elect representatives and to force their representatives to speak to their needs.

And the reason for the drive to organize in the black community is the need for psychological equality. For the advocates of Black Power, the reality of America is that it is a nation that is racist from top to bottom.

How do the advocates of Black Power, Stokely Carmichael and the rest, see the United States? They see this country like an octopus of exploitation, "its tentacles stretching from Mississippi and Harlem to South America, the Middle East, Southern Africa, Vietnam." They see the United States as a great colonial power, and its colonies include the black ghettos within its borders, north and south. A totally different America must be born if the racism which sustains this pattern is to die.

White society, according to the advocates of Black Power, prefers to talk about integration. Integration means the man who makes it, it means that a man leaves his black brothers behind in the ghetto as fast "as his new sports car will take him," as Stokely Carmichael puts it. And integration speaks to the problem of blackness in a despicable way. It assumes, or rather it is based on a complete acceptance of the notion that in order to have a decent house or an education, blacks must move into a white neighborhood or send their children to a white school. This reinforces among both black and white the idea that white is automatically better, and black is automatically inferior. Integration, therefore, is a subterfuge, allowing the nation to focus on a few Southern children getting into white schools while ignoring the 94\% who are left behind in unimproved, all-black schools.

What the advocates of Black Power are driving for is really a psychological equality. What they want to achieve is the revolutionary idea that black people are able to do things themselves. And the only way to bring this about, they believe, is through an aroused and continuing black consciousness. Black people must do things for themselves; they must get poverty money they will control and spend themselves, they must conduct tutorial programs themselves, so that black children can identify with black people. 
America is racist from top to bottom, and this racism is not a problem of human relations, but of a pattern of exploitation maintained actively or silently by society as a whole. And the rebuilding of society is not primarily a task of the blacks; it is the responsibility of the whites.

\section{COMMENTARY BY RABBI CHAIM SEIDLER-FELLER}

Leonard was my mentor in social justice and in rabbinic dignity. It is an honor for me to comment on his "Notes for the Symposium on Black Power." Although I will take issue with him, I consider my reflections to be part of our ongoing conversation.

The primary problem with the call for Black Power was its overt appeal for separation and its concomitant identification of all white people as the enemy. The movement rhetoric was inflammatory, and the trappings of violence were evident from its inception. As a rule any call to power that is not contextualized in a constructive framework will quickly degenerate into militancy and will eventually selfdestruct. And disenfranchisement never constitutes a license for nihilistic violence.

What's more, as a strategy, revolutionary zeal intended to overthrow the extant system was bound to fail. Social, political, and economic changes in American society were traditionally the result of evolutionary forces that worked to transform the system from within. Our deeply rooted commitment to justice as articulated in our foundational principles laid claim to all Americans. Martin Luther King's success was a function of the fact that his pursuit of rights for African Americans was framed as a campaign for a better America for everyone. Psychologically and societally my own commitment to civil rights is a product of my having internalized the moral imperatives of the Jewish tradition that compel me to act on behalf of the vulnerable and of my contractual responsibility (obligation?) as a citizen to America as a whole. 